\title{
Climate Change and Obesity
}

\section{(ㄷ) (i) ()ㅇ $\ominus$}

Authors

Christian A. Koch ${ }^{1,2}$, Pankaj Sharda ${ }^{1}$, Jay Patel ${ }^{2}$, Sriram Gubbi ${ }^{1}{ }^{\mathbb{D}}$, Rashika Bansal ${ }^{3}$, Michael J. Bartel ${ }^{1}$

\author{
Affiliations \\ 1 Department of Medicine, Fox Chase Cancer Center, \\ Philadelphia, PA, USA \\ 2 Department of Medicine, The University of Tennessee \\ Health Science Center, Memphis, TN, USA \\ 3 National Institutes of Health, Bethesda, MD, USA
}

Key words

climate change, greenhouse gas emission, temperature, endocrine disrupting chemicals, brown fat, metabolic rate, COVID-19, thermogenesis, obesity

received 14.06 .2021

accepted after revision $\quad 22.07 .2021$

Bibliography

Horm Metab Res 2021; 53: 575-587

DOI $10.1055 / \mathrm{a}-1533-2861$

ISSN 0018-5043

(c) 2021. The Author(s).

This is an open access article published by Thieme under the terms of the Creative Commons Attribution-NonDerivative-NonCommercial-License, permitting copying and reproduction so long as the original work is given appropriate credit. Contents may not be used for commercial purpose, or adapted, remixed, transformed or built upon. (https://creativecommons. org/licenses/by-nc-nd/4.0/)

Georg Thieme Verlag, Rüdigerstraße 14,

70469 Stuttgart, Germany

Correspondence

Prof. Christian A. Koch, FACP, MACE

Department of Medicine/Endocrinology

Fox Chase Cancer Center

333 Cottman Ave

Philadelphia, PA 19111

USA

Christian.koch65@gmail.com

\section{ABSTRACT}

Global warming and the rising prevalence of obesity are well described challenges of current mankind. Most recently, the COVID-19 pandemic arose as a new challenge. We here attempt to delineate their relationship with each other from our perspective. Global greenhouse gas emissions from the burning of fossil fuels have exponentially increased since 1950 . The main contributors to such greenhouse gas emissions are manufacturing and construction, transport, residential, commercial, agriculture, and land use change and forestry, combined with an increasing global population growth from 1 billion in 1800 to 7.8 billion in 2020 along with rising obesity rates since the 1980s. The current Covid-19 pandemic has caused some decline in greenhouse gas emissions by limiting mobility globally via repetitive lockdowns. Following multiple lockdowns, there was further increase in obesity in wealthier populations, malnutrition from hunger in poor populations and death from severe infection with Covid-19 and its virus variants. There is a bidirectional relationship between adiposity and global warming. With rising atmospheric air temperatures, people typically will have less adaptive thermogenesis and become less physically active, while they are producing a higher carbon footprint. To reduce obesity rates, one should be willing to learn more about the environmental impact, how to minimize consumption of energy generating carbon dioxide and other greenhouse gas emissions, and to reduce food waste. Diets lower in meat such as a Mediterranean diet, have been estimated to reduce greenhouse gas emissions by $72 \%$, land use by $58 \%$, and energy consumption by $52 \%$.

\section{Introduction}

Obesity, a global pandemic, represents a major health challenge with individuals affected with a weight stigma being less likely to receive adequate care $[1,2]$. Conversely, excellent patient aware- ness of obesity as a health problem but misperception of obese status and unawareness about body mass index is high in certain ethnic groups $[3,4]$. Obesity affects more than 680 million adults worldwide and is present in nearly $40 \%$ of U.S. adults with $61 \%$ of 


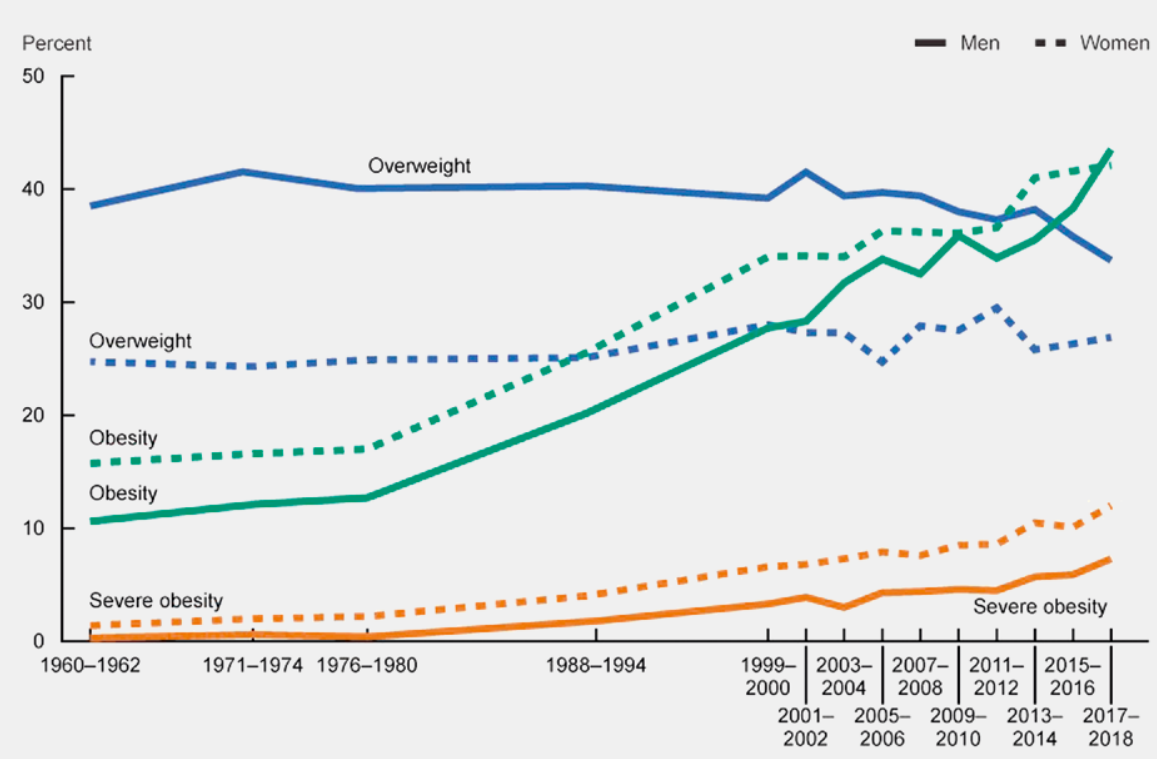

Fig. 1 Age-adjusted trends in overweight, obesity, and severe obesity among men and women aged 20-74: United States, 1960-1962 through 2017-2018.

\section{Global Greenhouse Gas Emissions by Gas}

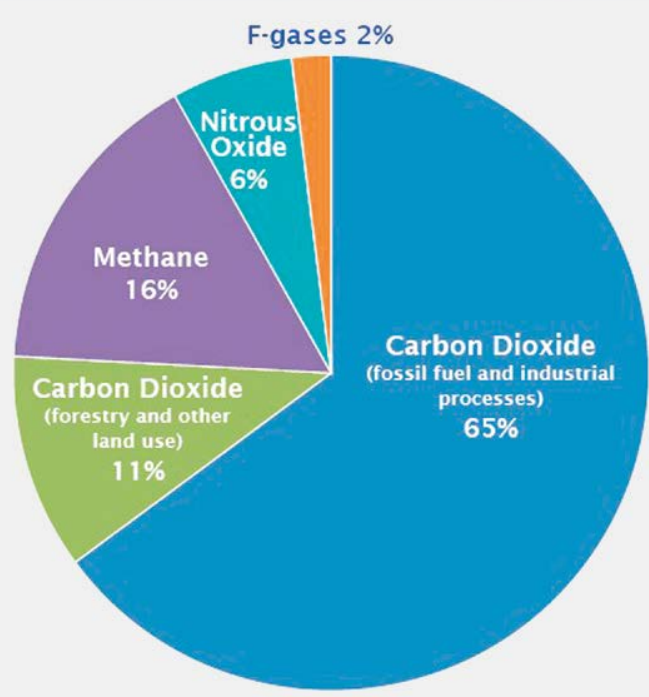

-Fig. 2 Global greenhouse gas emissions by gas. (source: https:// www.epa.gov/ghgemissions/global-greenhouse-gas-emissions-data).

patients diagnosed with diabetes mellitus being obese. Worldwide, obesity has nearly tripled since 1975 and most of the world's population live in countries where overweight and obesity kills more people than underweight [5]. Obesity is associated with risk of various malignancies including breast and endometrial cancers, cancer of the esophagus, gastric cardia, colon, rectum, liver, gallbladder, pancreas, kidney, thyroid gland, and multiple myeloma $[6,7]$. Figure 1 demonstrates the age-adjusted trends in over- weight, obesity, and severe obesity among men and women from age 20 to 74 years in the United States, 1960-1962 through 20172018 [8].

In 1856, Eunice Newton Foote (1819-1888) first reported that changing the proportion of carbon dioxide in the atmosphere would change its temperature [9]. The most abundant greenhouse gases in Earth's atmosphere are water vapor, carbon dioxide $\left(\mathrm{CO}_{2}\right)$, methane, nitrous oxide, ozone, and fluorinated gases including chlorofluorocarbons and hydrofluorocarbons [10].

The United States Environmental Protection Agency published global greenhouse gas emissions by gas ( $>$ Fig. 2). These emissions are produced from using electricity generated from oil, natural gas, and coal, burning oil or gas for home heating, or from burning gasoline when driving vehicles ( $\mathbf{F i g}$. 3a, b) [11]. Deforestation has released and will continue to release carbon dioxide and has become a major problem worldwide.

The main source of anthropogenic methane emissions is agriculture, for instance, ruminant livestock such as sheep and cows, and anaerobic decomposition of organic material in flooded rice paddies. The atmospheric concentration of $\mathrm{CO}_{2}$ has dramatically increased since the beginning of the Industrial Revolution, from 280 part per million in 1750 to 415 ppm in 2019 with approximately 90 ppm occurring within the last 56 years $[11,12]$.

Among the top ten emitting countries accounting for approx. $70 \%$ of the world's annual energy-related carbon $\mathrm{CO}_{2}$ emissions are China, the United States, India, Russia, Japan, Germany, South Korea, Iran, Canada, and Saudi Arabia.

In 2019, the EAT-Lancet commission published an extensive paper and first full scientific review on the definition of healthy diets from sustainable food systems and on which actions are able to support and accelerate food system transformation in the current time and geological epoch, named the Anthropocene [13]. This 


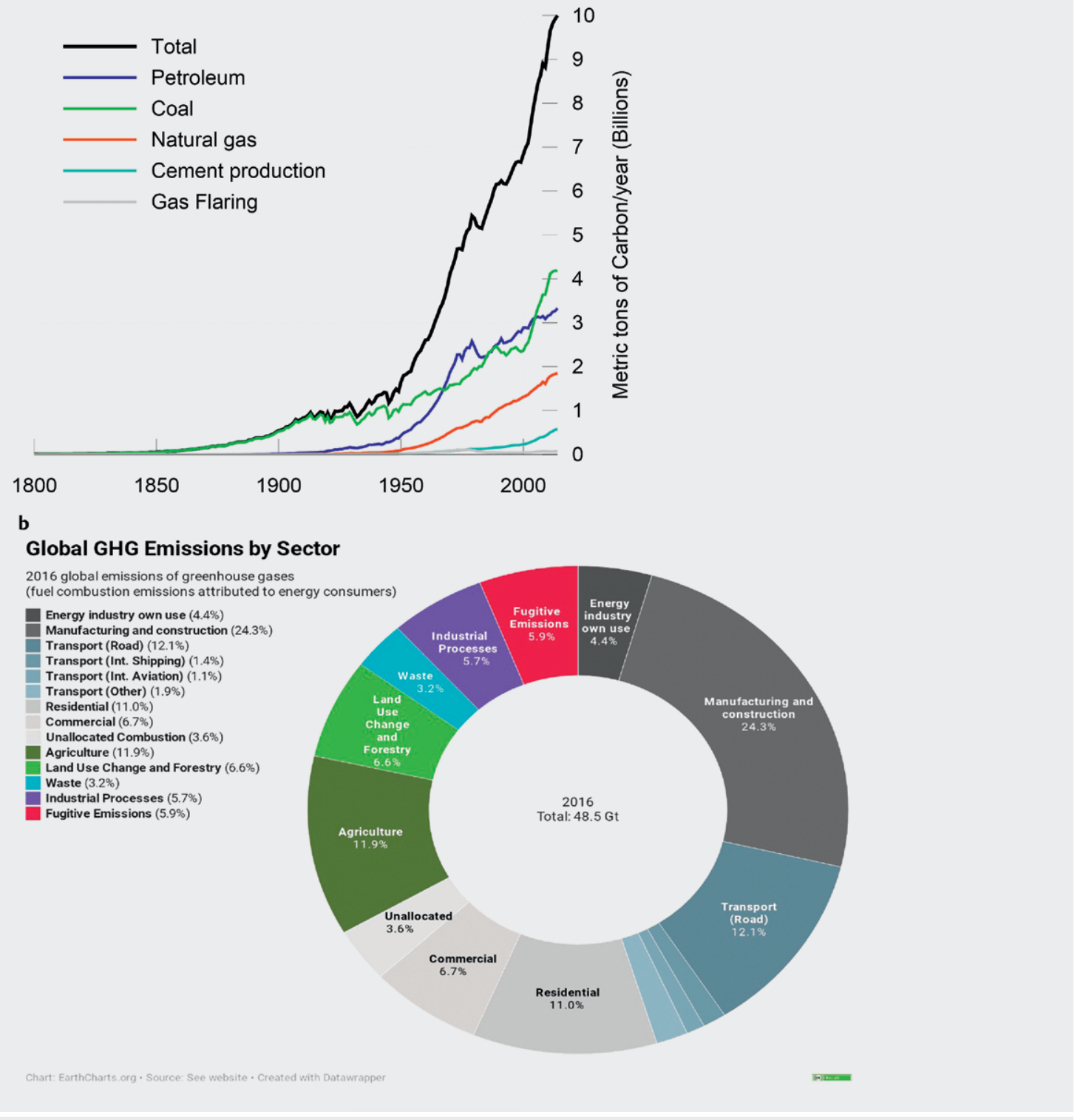

- Fig. 3 a: Modern global $\mathrm{CO}_{2}$ emissions from the burning of fossil fuels. (https://en.wikipedia.org/wiki/Greenhouse_gas_emissions); b: 2016 Global greenhouse gas emissions by economy sector. Percentages are calculated from estimated global emissions of all Kyoto greenhouse gases, converted to $\mathrm{CO}_{2}$ equivalent quantities $\left(\mathrm{GtCO}_{2} \mathrm{e}\right)$. GHG: Greenhouse gas. (source: https://en.wikipedia.org/wiki/Greenhouse_gas_emissions; http:// earthcharts.org/category/climate-change/).

detailed report starts with an executive summary stating that 820 million people are not having sufficient or high-quality food which contributes to the rising incidence of diet-related obesity. The authors of this paper concluded that there is strong evidence "indicating that food production is among the largest drivers of global environmental change by contributing to climate change, biodiversity loss, freshwater use, interference with the global nitrogen and phosphorus cycles, and land-system change and chemical pollution." As of now, the global population is estimated at 8 billion people and predicted to grow to 10 billion by $2050[13,14]$. To what extent the growth and number of the world population will be affected by future pandemics such as the Covid-19 pandemic is uncertain [15-17].
In this article we review the bidirectional interaction between climate change/global warming and human metabolism/adiposity.

\section{Economics}

The relationship between economic growth and environmental degradation is shown in the environmental Kutznets curve (EKC). The EKC hypothesis presents a bell-curved relationship between economic growth and $\mathrm{CO}_{2}$ emissions and its validity in the context of Vietnam has recently been studied [18]. In that study, Vo and Ho utilized the auto-regressive distributed lags (ARDL) model to investigate both short-term and long-term relationships between variables and grouped different energy consumption types into two 
main categories: a) fossil energy consumption including coal, gas, and oil consumption, and b) renewable energy consumption including hydroelectric consumption for which Vietnam seems to be suited given its massive network of rivers and major lakes. The authors also performed a threshold regression to determine the per capita gross domestic product level. Several studies examining the validity of the EKC hypothesis conclude that $\mathrm{CO}_{2}$ emissions will increase as income increases to a certain level. Aslan et al. [19] found that the effect of economic growth on $\mathrm{CO}_{2}$ emissions in the United States of America was increasing from 1982 to 1996 and decreasing from 1996 to 2013. In Vietnam, $\mathrm{CO}_{2}$ emissions have increased approximately ten times while economic growth has increased five times from 1986 to 2018 [18]. Energy consumption has tremendously increased, 14 times by fossil sources and more than 50 times by renewable energy sources [18]. The annual economic growth rate has been maintained above $5 \%$ since 1988, principally supported by foreign direct investment which seems to improve environmental quality at the lower threshold of economic growth and in the short-run. An increase in foreign direct investment and consumption of fossil fuel energy deteriorates the environment in the long run at any level of economic growth in Vietnam. The authors Vo and Ho believe that this data can also be useful for other developing and emerging markets.

\section{Possible Effects of Global Warming on Adiposity}

It is believed that the effects of food production on emissions of $\mathrm{CO}_{2}$, methane, nitrous oxide, and ozone, referred to as primary greenhouse gases in the atmosphere of the planet Earth, will reduce the stability of the Earth system. The first systematic review on the relationship between global warming and the obesity epidemic, including 50 studies published in or after 2002 attempted to find answers for the questions whether global warming and the obesity epidemic share common determinants, whether one influences the other and/or each other, and which pathways would underlie such a relationship [20]. The authors of this review constructed a conceptual model linking global warming and the obesity epidemic: a) Land use, urbanization, motorized transportation and agricultural productivity which is affected by population growth, industrialization and the fossil fuel economy, b) These factors influence global warming by excess greenhouse gas emission and impact the obesity epidemic by nutrition transition and physical inactivity, c) global warming directly affects obesity by food supply/price shock and adaptive thermogenesis, and d. the obesity epidemic contributes to global warming by elevated energy consumption.

Kanaszawa [21] argues that endotherms acquire more calories by eating food at a higher temperature than eating the identical food cold and that atmospheric temperature correlates with small increases in weight based on an analysis of the National Longitudinal Study of Adolescent to Adult Health.

\section{Fat Tissue and Thermogenesis}

As reviewed in Turner et al. [22], obese men typically have the largest adipose tissue thickness in the abdominal region, whereas obese women accumulate excessive fat at the femoral and gluteal regions [23]. Initial fat cell weight enlargement (up to $0.8 \mu \mathrm{g}$ per cell in each region) is followed by an increased fat cell number [23]. Figurines of women with obesity from Upper Paleolithic Europe rank amongst the earliest art and may relate to human adaptation to climate change, as during this time period from 38000 to 14000 before present, humans faced advancing glaciers and falling temperatures leading to nutritional stress and a reduction in the population [24].

Obesity may be associated with $20 \%$ greater emissions from greenhouse gases compared with the normal weight state. This is the result from oxidative metabolism due to greater metabolic demands, from food production processes due to increased food intake, and from automobile and air transportation due to greater body weight [25].

Energy balance is a key concept in developing strategies to fight obesity. This balance is affected by calorie intake, physical activity and by energy dissipation [26].

Physical activity/exercise includes endurance and resistance training, both leading to adaptive changes in skeletal muscle and production and secretion of myokines including irisin which besides myogenesis can switch white adipocytes to brown fat-like cells, causing an increase in energy expenditure [27-29]. Shortterm metformin treatment does not change brown adipose tissue (BAT) activity in women with polycystic ovarian syndrome [30].

Obesity can be promoted by impaired thermogenesis, for instance, by decreased expression of thermogenesis related genes encoding uncoupling proteins, thyroid hormone receptors, beta adrenergic receptors, and 5'-iodothyroxine deiodinases [31]. Bisphenol A, a chemical produced in large quantities of polycarbonate plastics and epoxy resins and found in food and drink packaging, is an endocrine disrupting chemical which can affect the metabolism of thyroid hormone by inhibiting type 1 iodothyronine deiodinase [32].

Adaptive thermogenesis is defined as the complex response of homoeothermic organisms to increase the rate of energy expenditure above normal baseline levels during exposure to cold in order to maintain core temperature [33].

The adaptive thermogenesis response shows large inter-individual variability. With cold exposure, South Asians showed lower resting energy expenditure, non-shivering thermogenesis, and brown adipose tissue volumes compared to Caucasians [34].

The process of thermogenesis in which brown or beige adipocytes contribute to increased energy expenditure is not fully functional in all populations. Studies have shown that increased time spent in a thermal neutral zone (the range of ambient temperatures at which the metabolic rate is minimal) can lead to a loss of brown adipose tissue and reduced thermogenic capacity (reviewed by Johnson et al. [35]). With the advancements of central heating and air conditioning in homes, transportation and businesses, a cultural shift in ambient temperature exposure towards that of thermal comfort has occurred. While specific data on indoor temperatures varies with different collecting strategies and protocols, the overall upward trend of indoor temperatures during the winter months is prevalent [36,37]. People are spending less time exposed to temperature extremes and more time in temperature-controlled "comfortable" environments. 
Thermogenesis makes up about $10 \%$ of total energy expenditure which plateaus above moderate physical activity levels [38]. Diet-induced thermogenesis is determined by the diet consumed. Energy released in form of heat is the lowest for fat (2\%), followed by glucose ( $8 \%$ ), protein (20-30\%), and alcohol (22\%) with large inter-individual variability determined by genetic factors, gender, various hormones and the sympathetic nervous system activity [37]. Thyroid hormone regulates the basal metabolic rate and energy expenditure. Cold-induced thermogenesis is higher in euthyroid compared to hypothyroid individuals [39].

Ambient temperature exposure thus plays an important role in BAT activity. As the thermogenic activity of BAT is stimulated by cold exposure, more time spent in the thermal comfort zone will lead to loss of BAT activity, thereby decreasing energy expenditure with potential obesogenic consequences. Brown adipose tissue plays a role in the development and treatment of nonalcoholic steatohepatitis, a liver condition which can promote the chronic inflammatory state in obese individuals [40].

Overweight and obese adults are at greater risk for heat-related illness or injury [41]. Obese older adults were twice as likely to die during the 2003 European heatwave compared to non-obese individuals [42]. Heatstroke occurs much more frequently in obese or overweight people compared to normal weight individuals because of reduced ability to dissipate heat $[41,43,44]$.

Elevated air pollution with ambient particulate matter 2.5 contributes to climate change and is linked to reduced physical activity [45].

\section{Climate Change}

At the current emission rates, the United Nations' Intergovernmental Panel on Climate Change (IPCC) estimated that temperatures could increase by $2^{\circ} \mathrm{C}$ by 2036 . In Germany where two of the authors of this article were born, weather documentations since 1881 indicate that the air temperature increased by $1.5^{\circ} \mathrm{C}$ in 2020 in Germany ( $\triangleright$ Fig. 4), while it increased globally by $1^{\circ} \mathrm{C}$. Since the year 2000 , sea levels are rising, and the number of extreme weather events has increased including prolonged heat waves and flood rains.

Climate experts in Germany estimate summer temperatures to be as hot as $45^{\circ} \mathrm{C}$ by the year 2100 with a desert landscape in many German regions similar to the area around Dabuleni in Southern Romania, if the Paris Agreement will not be met (Klimawandel. Die Fakten mit Harald Lesch. ZDFzeit 28.2.2021 und 21.10.2020). This agreement represents a legally binding international treaty on climate change and was entered into force in November 2016. Its goal is to keep the increase of global mean temperature to below $2{ }^{\circ} \mathrm{C}$, compared to pre-industrial levels [46]. Since 1950 the number of dry soil areas and droughts in Germany have increased with an approximate water deficit of 500 liters per square meter. The rapeseed harvest in Brandenburg, Germany, has declined by $20 \%$ because of increasing droughts. The reason for these extreme weather events, not only in Germany but also in the United States and other regions of the world, is a weather pattern called omega block. Deforestation aggravates this problem. Although $32 \%$ of Germany

\section{German Climate Atlas}

\section{Germany \\ May 2021 \\ Air temperature}

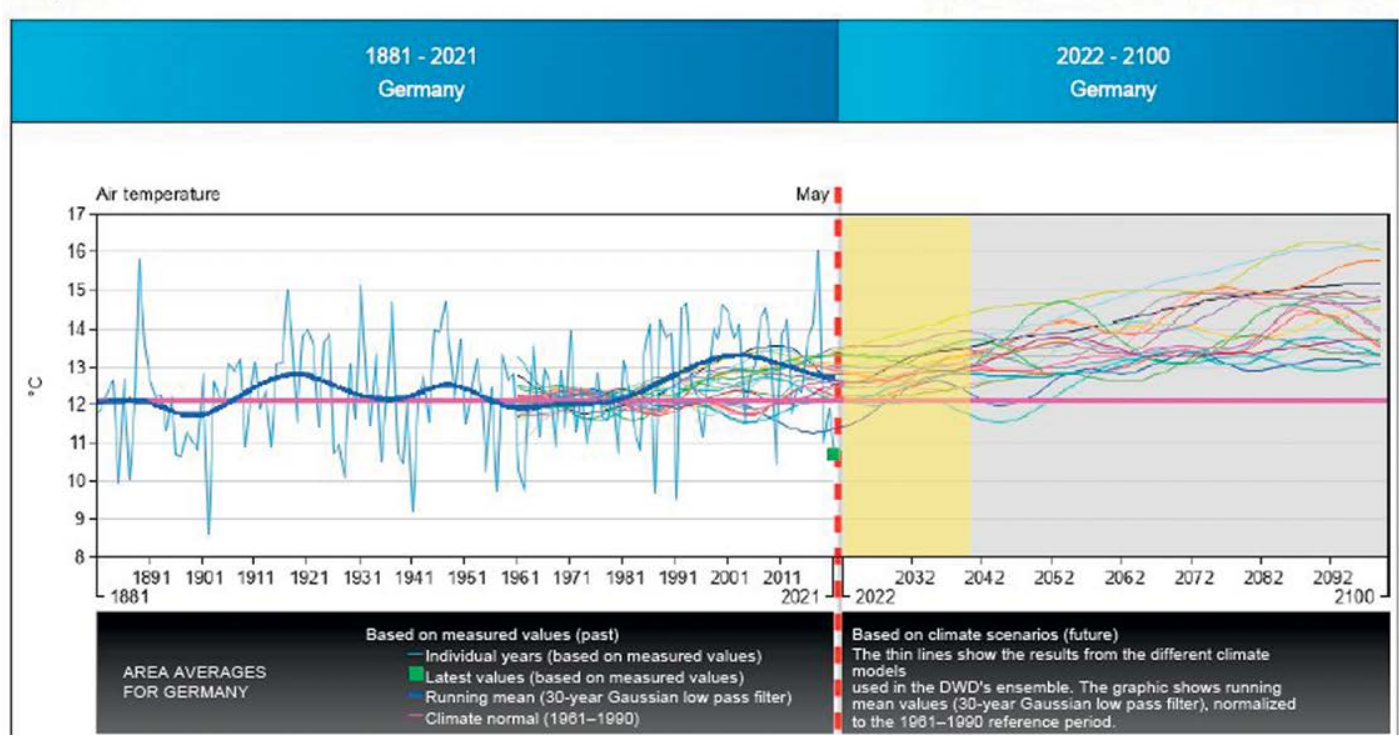

The German Climate Attas published by the DWD presents an at-a-glance overview of our past, current and future climate, giving a very good summary of how the averages of climate parameters
presented here have so far changed in Germany and its federal states (Länder) and in what direction they are likely to change in the future. The time series plots show the annual values and as smoothed means (using a Depending on the databases, the beginning of the time series varies between 1881 and the middle of the 2 The results of the different regional 1961-1800 reference period. They are also represented as smoothed means (using a 30-year Gaussian low pass fiter). The currently valid climate norma (reference period: $1861-1990$ ) is plotted as a continuous line to aid orientation. unw. dwod.de/klimaatlas

Fig. 4 German climate atlas (source: www.dwd.de). 
is covered with forest, $40 \%$ of that forest is badly damaged leading to forest dieback. Trees can bind $14 \%$ of greenhouse gas emissions $\left(\mathrm{CO}_{2}\right)$ and enable the soil to keep water and moisture. Water deprivation of especially spruce trees make them prone to become infested with the bark beetle, which then further promotes forest dieback. In 2018, the level of the Elbe river near Dresden measured only $18 \mathrm{~cm}$ and the level of the Rhine river near Emmerich $7 \mathrm{~cm}$, making such main waterways impassable for shipping, thereby leading to a transportation problem of major goods [47].

The Baltic Sea water temperature is now $1.9 \%$ warmer in 20 meter depth than in 1980. Concomitantly there is a rise of dead herring and overall reduction of the Baltic Sea herring number which will change the food chain over time. The North Sea water temperature has increased by $1.3^{\circ} \mathrm{C}$ during the twentieth century and the water level at Pellworm (Germany) has risen by $25 \mathrm{~cm}$. Along with rising sea levels there is a retreat of glaciers since 1850 . In the Alps, the ensuing lack of glacier water can lead to reduction of drinking water. Indeed in summer 2020, there was a shocking shortage of drinking water in Lauenau, Germany. In Helgoland, the technique of reverse osmosis is utilized to obtain drinking water under high energy consumption.

Hard evidence for the irrefutable fact that global warming and climate change exist is the recent break/ice calving of iceberg A-68, that one might call the "tipping point" of climate change [48]. This giant iceberg with a surface area of 5800 square kilometers (2200 square miles) and an estimated weight of one trillion tones, broke up/off from the Larsen C ice shelf in Antarctica on July 12, 2017. However, this did not happen suddenly, as scientists identified the start of the ice cracking in November 2016, forming a lace-network of cracks. Since 1940 the air temperature in Antarctica rose by $0.5{ }^{\circ} \mathrm{C}$ every 10 years to a total of $4{ }^{\circ} \mathrm{C}$ now. Continental ice pressures shelf ice leading to an increase in energy and temperature. With an increase in air temperature, an increase in water temperature occurs and ice will melt. Via satellites, radar, and infrared cameras, it has become possible to watch the ice moving following the Bernoulli principle which states that an increase in the speed of a liquid happens simultaneously with a decrease in static pressure or a reduction in the fluid's potential energy. Satellite images from the European Space Agency show the iceberg A-68 moving towards South Georgia Island and that it has broken up in major fragments in December 2020.

It is obvious that such events contribute to rising sea levels. Furthermore, "Atlantification" of the Arctic promotes rising sea levels and is characterized by warmer ocean temperatures and a reduced sea ice cover, currently well observed at the Barents Sea [49]. In the Arctic, the East Siberian and Laptev Sea harbor methane deposits. Arctic warming by a few degrees Celsius may lead to permafrost thawing, coastal erosion, and the release of methane and $\mathrm{CO}_{2}$ into the atmosphere, likely further worsening global warming [50].

\section{Potential Solutions to Remove Greenhouse Gases from the Atmosphere}

On an individual level, one should learn more about how to contribute to less consumption of energy generating $\mathrm{CO}_{2}$ and other greenhouse gas emissions. This could include forcing construction companies to higher standards regarding the insulation of residenc- es and homes using material that demonstrates the best protection against heat and cold, particular as an estimated $6 \%$ of global greenhouse gas emissions derive from buildings. Exemplary spending less time in the thermal comfort zone could contribute both to decrease $\mathrm{CO}_{2}$ emissions and potentially affect obesity as well.

Transportation which accounts for $14 \%$ of the global greenhouse gas emissions is a valuable target for each of us willing to help decrease $\mathrm{CO}_{2}$ emissions for instance by bicycling, walking, or taking stairs instead of elevators, and taking the bus or car pool [51]. This is a major challenge for urban designers [52].

Considering that an electric car with a battery of $40 \mathrm{kWh}$ (kilowatt hour) has to drive $72000 \mathrm{~km}$ (45 000 miles) and one with a battery of $95 \mathrm{kWh}$ drives $166000 \mathrm{~km}$ (103 000 miles) to achieve an advantage regarding carbon dioxide emissions towards a car that uses gasoline, adding the environmental damage caused by the raw material used for the battery versus the raw material (steel, fiberglass) used for a traditional car, there does not seem to be an ecological advantage to increasingly use electric cars to help the climate change [53, 54].

On a community level, green/plant areas should be increased to help absorb $\mathrm{CO}_{2}$ via photosynthesis and improve the air quality, as well as combat extreme weather conditions with flood rains and episodes of drought and heat. The largest "green façade" project in Europe was completed in 2020 in Düsseldorf, Germany, with hornbeams and other plants covering the roofs of major buildings and providing some cooling in hot summer days when heat increases in the city because of concrete and little wind flow [55]. This is part of the climate change concept called "sponge city" with the idea to return back to the future of having ditches instead of canalization/sewerage several hundred years ago. However, this new urban construction model aims at flood management and urban heat problems. Rain water should be captured and repurposed for irrigation [56].

The Covid-19 pandemic showed clearly how humans contribute to the production of greenhouse gases. This pandemic, which dramatically impacted all of our lives, also had substantial impact on the economy, transportation, production in any sector, etc. and resulted in an estimated $17 \%$ decrease of daily global $\mathrm{CO}_{2}$ emissions when comparing April 2019 with April 2020 [57]. The COVID-19 pandemic showed how much humans contribute to and could positively impact greenhouse gas emissions.

Stopping deforestation and instead planting more trees to obtain a mixed forest (consisting of spruce,douglasie trees and also deciduous trees) can help to not only bind $\mathrm{CO}_{2}$, but also promote humus growth/development and act as a sponge that stores water. This may require reducing cattle ranching which often has the goal to export meat and drives further deforestation for soybean production fields. Another reason for deforestation is logging and the economic opportunity to export timber, in part used as charcoal. In the Amazon's tropical rainforest, deforestation has led to loss of biodiversity and threat of desertification [58].

In Scotland known for its moorland in the Scottish Highlands, sphagnum, commonly called peat moss, can store water and carbon. Therefore, this type of moss in climate terms is classified as being “ $\mathrm{CO}_{2}$ neutral”. Notable moorlands exist in Africa, Alaska, Europe, Russia, North and South America [59]. 
Drainage of the moors/swamps should be stopped and, instead, the focus should be to enrich these regions with water/"re-water" them. When air instead of water enters the soil of the moor/swamp, an aerob mineralization of organic substances in the moor soil takes place and it no longer serves as a carbon storage.

Agroforestry utilizes trees and shrubs that are grown around or among crops or pastureland. This could serve as windbreaker. Other practices include Riparian forest buffers, forest farming, alley cropping, and silvopasture [60].

In terms of forests, the last word, however, has not been spoken. Canadian forests, for example, were net emitters of $\mathrm{CO}_{2}$ in 2017 and 2018 due to wildfires and several practices such as slash burning [61]. This delineates the importance of planting new trees, maintaining forests, keeping them "healthy" and addressing outbreaks like the pine beetle which impact indirectly $\mathrm{CO}_{2}$ emissions. Wood will remain an important natural product in our daily lives and sustainability of wooden products must be paramount to us.

Carbon capture and storage (CCS) can reduce greenhouse gas emission rates [62]. This can be accomplished by removing $\mathrm{CO}_{2}$ from the atmosphere under high pressure into geologic formations such as depleted oil and gas reservoirs, unmineable coal seams, and deep saline reservoirs, or into the soil. Impermeable cap rock typically prevents the $\mathrm{CO}_{2}$ from leaking back to the surface. Deep ocean storage could acidify the ocean. When CCS is combined with biomass it can result in net negative emissions. At present, the two largest-scale power plants with CCS are Petra Nova Carbon Capture in the United States and Boundary Dam CCS in Canada. Natural gas power stations usually emit less $\mathrm{CO}_{2}$ than coal-fired power plants. CCS can capture more than 800000 tons of $\mathrm{CO}_{2}$ per year at a large coal-fired power plant. In the United Kingdom, one ton of $\mathrm{CO}_{2}$ from the atmosphere could be removed by the Drax power station in North Yorkshire, England, in 2019. In Norway, depleted oil and gas reservoirs are considered for CCS and scientists from all over the world are searching for regions to deploy CCS technology offshore. The Northern Lights initiative, supported by the Norwegian government, the French multinational integrated oil and gas company Total SE, the energy company Equinor ASA, and the Royal Dutch Shell PLC, intends to store 1.5 million tons of $\mathrm{CO}_{2}$ per year under the North Sea starting in 2024 [63]. In Japan under the CCS demonstration project in Tomakomai city, the Ministry of Economy, Trade and Industry, injected 300000 tons of $\mathrm{CO}_{2}$ underground in November 2019 [64].

In Iceland, known for its volcanoes, CCS has been adapted for the black basalt rock. $\mathrm{CO}_{2}$ released from manufacturing plant smokestacks is captured and injected into the Icelandic basalt rock in approximately $500 \mathrm{~m}$ depth. The typical CCS procedure would separate $\mathrm{CO}_{2}$ from other gases, transport it via pipeline or ship to a suitable site, and then inject it deep underground where it turns into carbonate material such as calcite known as component of marble and limestone (based on sufficient amounts of calcium, magnesium, iron). In Iceland, the adapted CCS method is called CarbFix which involves dissolving $\mathrm{CO}_{2}$ in water before or during injecting it into the porous basalt rock. This makes $\mathrm{CO}_{2}$ less buoyant allowing it to sink down through the rock and reducing the risk of $\mathrm{CO}_{2}$ escape into the atmosphere. Mineralization of $\mathrm{CO}_{2}$ is facilitated by higher temperatures with $20-50{ }^{\circ} \mathrm{C}$ typically being sufficient for rapid mineralization. Volcanic Iceland has many high tempera- ture zones with underground temperature reaching $250{ }^{\circ} \mathrm{C}$ within 1 kilometer depth. In low temperature zones, the temperature still reaches up to $150{ }^{\circ} \mathrm{C}$ within 1 kilometer depth [65].

\section{Endocrine Disruption}

Global warming impacts ecosystems. Yacine et al. [66] investigated simulated trophic networks of co-evolving consumers to warming under different evolutionary scenarios and concluded that the long term diversity loss triggered by warming is higher in scenarios where evolution is slowed down or switched off, suggesting that eco-evolutionary feedback helps preserve biodiversity. The authors warn that reversing warming may not be sufficient to restore previous structures. Climate change with altered temperatures can cause endocrine disruption in humans and in animals [67] ( $\mathbf{F i g . 5}$ ).

Food contact plastics, some pesticides, flame retardants, perfluorinated compounds, and other endocrine disrupting chemicals (EDC) are derived from oil, coal, or gas $[68,69]$. Rising temperatures during climate change likely impact insect populations. Pesticide use significantly contributes to biodiversity loss [70], acknowledging that the use of pesticides and fertilizers combined with deforestation are the main drivers of biodiversity loss. Many EDCs are lipophilic, can promote adipogenesis, and cause weight gain and tumor growth [5, 71].

Endothermic animals, which need to maintain a constant internal body temperature for optimal metabolic function face a crucial challenge due to the necessity of complex thermoregulatory mechanisms. Several endocrine changes occur when an endothermic animal adapts to hot temperatures. Neuroendocrine mechanisms reduce food intake and metabolism in hot environment. This leads to reduced thyroid activity, reduced testosterone production, and the cortisol production initially increases and then decreases upon prolonged heat exposure [72]. On the contrary, cold temperatures cause elevations in adrenal steroidal hormones, and increase the activity in pituitary and thyroid glands. Prolonged cold exposure can cause thyroid and adrenal gland hypertrophy [72]. Experiments on quails, finch, and other bird species have demonstrated that thermal adaptation varies across species of endotherms [73]. Facultative hyperthermia also results in different incubatory and belly-soaking behaviors among different avian species [73]. Among mammals living in hot sub-tropical deserts, the thermoregulation depends on a combination of surrounding temperature and circadian cycles [73]. In general, migratory or nomadic animals tend to possess narrow temperature tolerance, while sedentary or non-migratory animals tend to better tolerate wider fluctuations in temperature [73]. Therefore, climate change can likely have a significant impact on the survival of migratory species. In addition, climate change and thermal fluctuations can also change parasite biology and parasite establishment, development, growth, and fecundity within their endothermic hosts [72].

Climate change can act synergistically with EDCs in creating endocrine disruption. There is growing concern for Arctic wildlife to inadequately adapt to changing climate due to damage inflicted by EDCs, especially on the thyroid, sex steroid, and glucocorticoid hormonal pathways [74]. In humans, knowledge of the impact of climate change on obesity and various endocrine systems is constantly evolving [22,75]. 


\section{Transmission and distribution of environmental endocrine disruptors in the ecosystem and food chain}

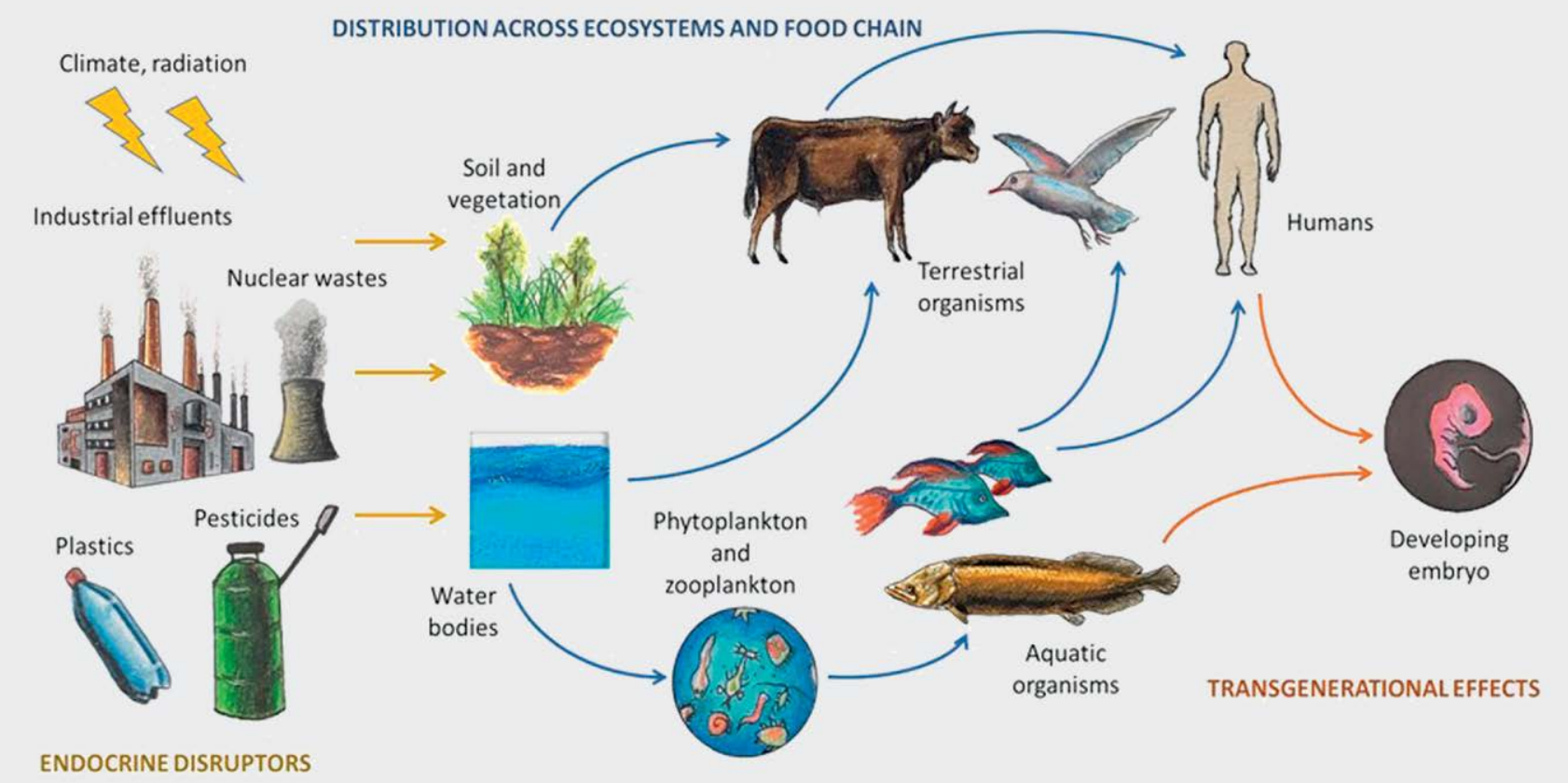

- Fig. 5 Transmission and distribution of environmental endocrine disruptors in the ecosystem and food chain.

An expert panel, charged with the task to quantify a range of health and economic costs that can be reasonably attributed to EDC exposures in the European Union, achieved consensus at least for probable (>20\%) EDC causation for childhood obesity, obesity, adult diabetes mellitus, and other disorders which are associated with costs in the hundreds of billions of Euros per year [76].

A big concern is the effect of changing global temperatures and their potential catastrophic impact on altering endocrine functions of flora and fauna on a global scale. Temperature increase, along with eutrophication in water bodies can increase metabolic demand in aquatic life and accelerated metabolic rates, thus resulting in hypoxic zones in the aquatic environment and further production of $\mathrm{CO}_{2}$ [77]. Elevated temperatures (to $30^{\circ} \mathrm{C}$ ), along with decreased $\mathrm{pH}$, and decreased water salinity delays growth in Pacific oysters (Crassostrea gigas). Variations in temperature have shown to cause differential effects in the body growth and gonadal size in tropical sea urchins (Tripneustes gratilla), with warming ocean temperatures increasing the susceptibility to disease and mortality among several species of sea urchins [78]. Water bodies harbor most of the life on the planet, with estimates of $\sim 80 \%$ of life on Earth thriving in the oceans. Change in the $\mathrm{pH}$ of water bodies, no doubt, will create a substantial impact on aquatic and terrestrial life, global carbon-cycle and in turn, the climate. A major effect of changes in $\mathrm{pH}$ is the acidification of the ocean. The devastating consequences of ocean acidification have been evident even from prehistoric times, and have been postulated to have contributed to mass extinctions, especially the infamous late-Cretaceous mass extinction from the Chicxulub meteor impact that wiped out a substantial amount of life on Earth, including the non-avian dinosaurs and several marine invertebrate and vertebrate species [79]. Climate change and ocean acidification often go hand-in-hand in causing major, or even catastrophic effects on biodiversity. This is because of the propensity of increasing $\mathrm{CO}_{2}$ levels in the atmosphere to cause a shift in the $\mathrm{CO}_{2}-\mathrm{HCO}_{3}$ equilibrium towards the acidic direction [77]. Changes in $\mathrm{pH}$ can also affect the dissociation status of endocrine disrupting chemicals, many of which happen to be weak acids/bases [77]. In addition, the concentrations of various metal ions can be affected by ocean acidification, which in turn can result in endocrine disruption [77]. Another major effect of pH changes and ocean acidification is its impact on water oxygenation levels. Deficiency or excess in water oxygenation can give rise to ROS which can exert toxic effects on the body, and on the endocrine system [77]. Low pH-mediated decrease in calcium carbonate mineral saturation can impair adequate tissue calcification and growth [78]. Low pH and low temperatures have been shown to reduce the success of fertilization, embryonic development, and size of the larvae and increase abnormal larval morphology in Sydney rock oyster (Saccostrea glomerate) and C.gigas. [80]. Similarly, low $\mathrm{pH}$ and acidification has also shown to reduce gonadal and body growth in T.gratilla [78]. Although data on the effects of $\mathrm{pH}$ on vertebrate animals and humans is sparse, future studies can potentially shed more light on this topic.

Acid rains are caused due to oxides of sulfur, nitrogen, and ozone, which predominantly originate from the combustion of fossil fuel [81]. Acid rains can lower the $\mathrm{pH}$ of water bodies, and this has resulted in a drop in populations of amphibians, molluscs, and phytoplankton [81]. Similarly, on terrestrial landscapes, acid rains have adversely affected the environment. Apart from altering the growth and physiology of trees and crop plants, acid rains can indirectly affect human health through liberation of toxic metals such as cadmium, lead, tin, mercu- 


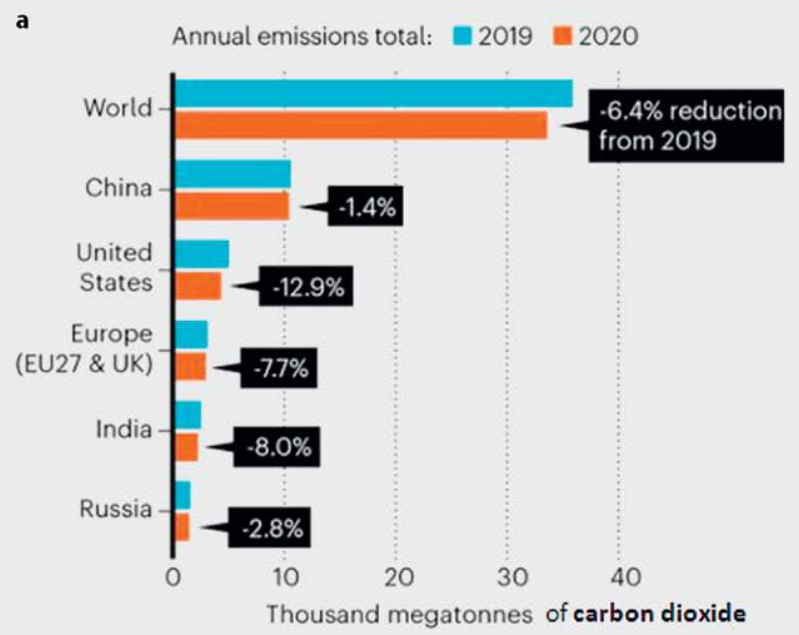

b

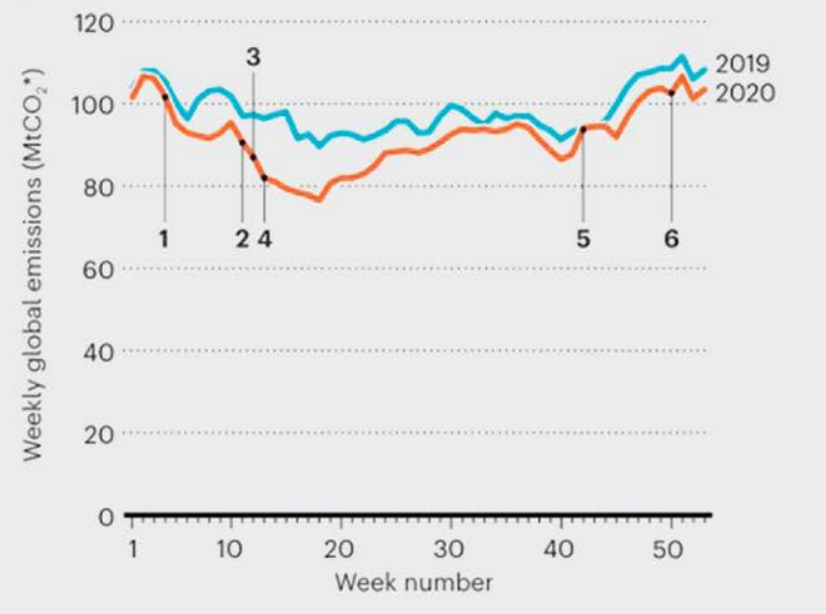

- Fig. 6 a: Carbon emissions; b: Carbon emission trend during Covid-19 pandemic. * Megatonnes of carbon dioxide. 1. China imposes lockdown on Wuhan, where coronavirus was first detected 2. Slammed by COVID, Italy issues a national lockdown 3. California becomes first US state to impose lockdown 4. India begins its first nationwide lockdown 5. As Europe surpasses 100000 new daily infections, countries announce new wave of restrictions 6 . California imposes a 3-week lockdown after registering its highest daily total of new infections.

ry, aluminum, iron, and manganese [81]. These metals could seep into ground water, which is consumed by humans, that could potentially lead to various endocrine abnormalities. Effects of acid rain on human health is an important area for further research.

\section{Obesity and Global Warming during the COVID-19 Pandemic}

The emergence and spread of SARS-CoV2 appears to be related to urbanization, habitat destruction, live animal trade, intensive livestock farming and global travel [82]. As of December 2020, $\mathrm{CO}_{2}$ emissions have declined in the year 2020 by $7 \%$ during the Covid19 pandemic ( $\triangleright$ Fig. 6 a, b) $[83,84]$.

The COVID-19 pandemic was shown to be associated with weight gain amongst adults and children in most countries. One of the interventions to prevent the spread of this potentially fatal virus has been to promote social distancing. This has been achieved by various stay at home orders from governmental agencies, one of them including school closures [85]. This intervention may increase risk of childhood obesity which is associated with various short and long-term illnesses like diabetes mellitus, hypertension, heart disease, stroke and certain cancers [86, 87]. Individuals with endocrine conditions are disproportionately affected by COVID-19 $[88,89]$. A recent systematic review and meta-analysis found that obesity is independently associated with an unfavorable outcome of COVID-19 illness with a $50 \%$ increased risk of death [90].

The shutdown of our social environments like work or school, reduced physical activity and the excess of free time during self-quarantine resulted in lifestyle changes and changes of our eating habits. Changes in the sleep pattern, excessive snacking, lack of diet restrictions, etc. were shown to be associated with weight gain during the COVID-19 pandemic [91]. Although no studies addressed metabolic changes of weight gain focusing on the COVID-
19 pandemic, one can speculate that they remain unchanged compared to the time prior to COVID-19. This dilemma can be tackled by an international modern training program in diabetes and metabolism such as the TransCampus metabolic training program in Dresden, Germany [92].

To reduce the risk of childhood obesity, the Physical Activity guidelines for Americans recommends 60 minutes or more of moderate-to-vigorous physical activity (MVPA) daily among children given physical inactivity is the major behavioral risk factor for obesity in children [93]. However, school closures, stay at home orders, parks and outdoor recreational activities closures thus have promoted an environment favoring obesity [94]. Children in recent times have been at high risk for energy imbalance and unhealthy weight gain [95]. To study the estimated impact of COVID-19 on childhood obesity, An studied this using a microsimulation model which showed an increase in mean body mass due to physical inactivity in kids [96]. Increasing the fitness level and keeping the body mass index at least stable are strategic initial goals for obese children [97].

\section{Possible Effects of Adiposity on Global Warming}

Swinburn et al. provide a detailed report including comparisons of the prevalence of female obesity rates and the carbon footprint (greenhouse gas emissions in tons per capita per year) between various regions of the world [75]. South Asia has a prevalence of female obesity of $5 \%$ and a carbon footprint of 2.2, whereas high-income English-speaking countries have a prevalence of female obesity of $33 \%$ and a carbon footprint of 18.5 [75].

Although there is debate whether eating four pounds of beef equals the emissions of a transatlantic flight and whether consuming a plant-based burger such as the start-up "Impossible Burger" instead will help solve climate change [98-100]. This start-up is 


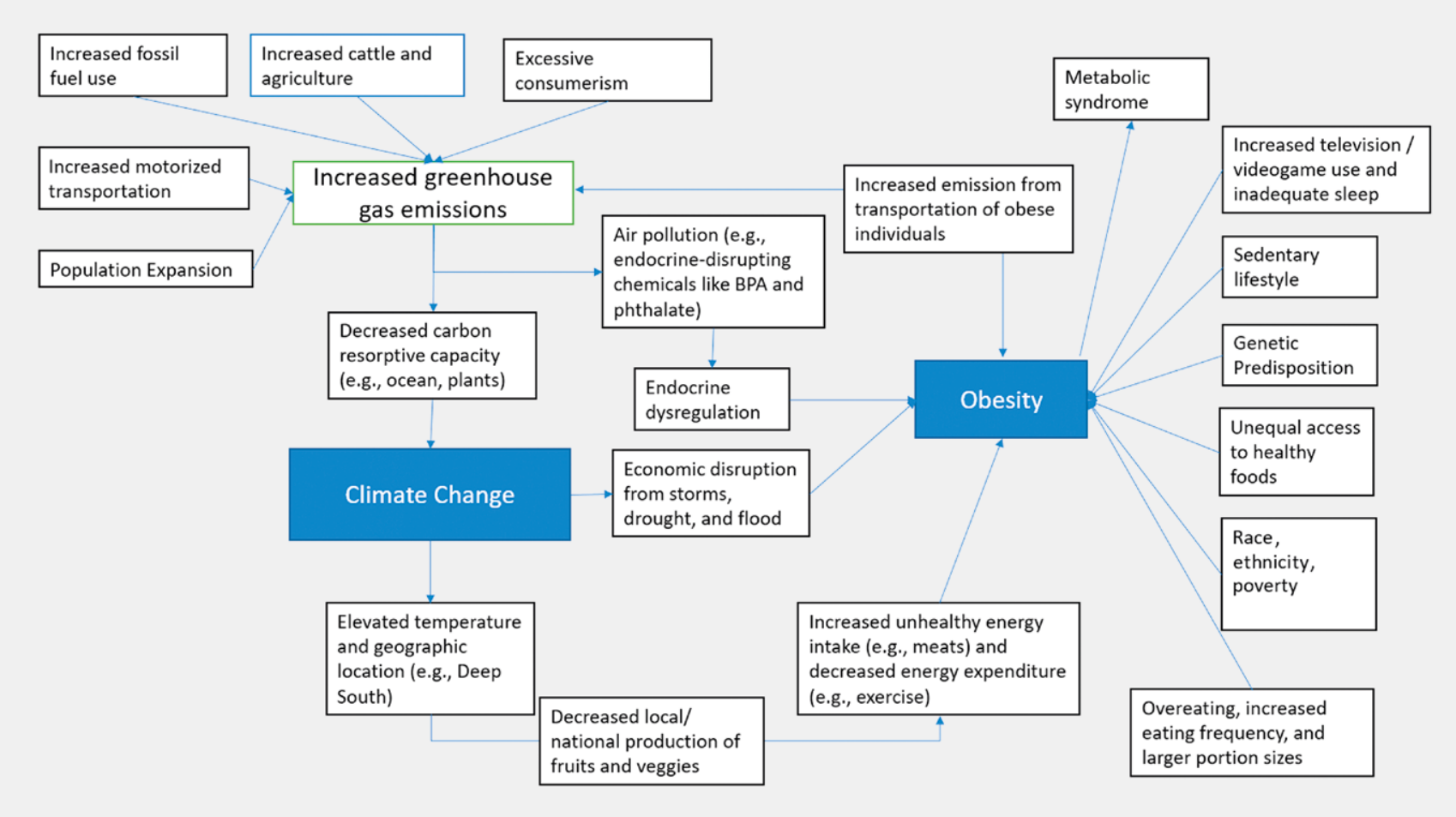

- Fig. 7 The bidirectional relationship between climate change/global warming and obesity.

made mainly of soy and potato proteins as well as coconut and sunflower oils [100]. A recent systematic review and meta-analysis of cohort studies concluded that an intake reduction of 3 servings of unprocessed or processed meat per week was associated with a very small reduction in overall cancer mortality over a lifetime [101]. Such a reduction of consumption of processed and unprocessed meat was also found to be associated with a very small reduction in risk for cardiovascular mortality, stroke, myocardial infarction, and type 2 diabetes [102, 103], the latter known to be also linked to obesity. Based on several such systematic reviews a nutritional recommendations consortium suggested that adults continue current unprocessed and processed meat consumption [104]. Agriculture land is used for livestock grazing and 33 percent of croplands are used to grow feed for livestock. According to data from the Environmental Protection Agency, livestock contributes to $9.3 \%$ of global greenhouse gas emissions [105].

The bidirectional relationship between climate change/global warming and obesity is shown in > Fig. 7 .

Climate change will likely disrupt food availability, reduce access to food, and making utilization more difficult and the overall stability of each (availability, access, utilization) [106].

Climate risks to food security are greatest for poor populations and in tropical regions. The coupled model intercomparison project for use in climate modeling experiments and assessment efforts developed representative concentration pathways (RCP) with RCP 2.6 being a low emissions scenario with extensive mitigation and a $\mathrm{CO}_{2}$ concentration of approx. 421 ppm by 2100 . This would lead to a global average temperature rise of approximately $1{ }^{\circ} \mathrm{C}$ by 2050 with no further change by 2100 , and a global average sea level increase of approx. $0.17-0.32 \mathrm{~m}$ by 2050 and $0.26-0.55 \mathrm{~m}$ by 2100 . The RCP 8.5 repre- sents a high emissions scenario, where emissions continue to increase rapidly, producing a $\mathrm{CO}_{2}$ concentration of $936 \mathrm{ppm}$ by 2100 , resulting in a global average temperature rise of approximately $2{ }^{\circ} \mathrm{C}$ by 2050 and $4{ }^{\circ} \mathrm{C}$ by 2100 . Global average sea level rise would be approx. $0.22-$ $0.38 \mathrm{~m}$ by 2050 and $0.45-0.82 \mathrm{~m}$ by 2100 . Socioeconomic models, which include climate change generally show an increase in food prices. Utilization rates are affected by food waste that occurs as a result of climate sensitive activities during food storage, processing, packaging, and trade. Food waste in the United States seems to account for 1 pound of food per day and to generate $8 \%$ of global greenhouse gas emissions [107]. Diets lower in meat such as a Mediterranean diet, have been estimated to reduce greenhouse gas emissions by $72 \%$, land use by $58 \%$, and energy consumption by $52 \%$ [108-110]. In the end, energy expenditure including caloric intake remain a key component of weight maintenance regardless of diet type [111] . Successful long-term weight loss is difficult to achieve and a workshop at the National Institute of Diabetes and Digestive and Kidney Diseases was held to discuss the physiology of the weight-reduced state [112]. The accumulation of data on key biological factors combined with behavioral, psychosocial, and environmental factors can help designing and delivering effective and tailored obesity treatments [113]. The overall placebo-subtracted weight reduction for at least 12 months can range from 2.9 to $6.8 \%$ for the anti-obesity drugs phentermine/topiramate, liraglutide, naltrexone/bupropion, and orlistat [114]. In obesity prevention, it is also important to be aware of weight gain and body fat redistribution as common side effects of many widely used medications such as antipsychotics [115].

In summary, there is a bidirectional relationship between climate change/global warming and adiposity. Strategies that improve the health of each individual on the planet and "save the planet" will meet 
challenges in various parts of the world simply by political will, economic considerations, cultural differences, infrastructure, and many other factors. In the end, each individual has to try to make her/his own best effort and contribution to live a healthier life.

\section{Conflict of Interest}

The authors declare that they have no conflict of interest.

\section{References}

[1] Purnell JQ. Definitions, classification, and epidemiology of obesity. In: Feingold KR Anawalt B, Boyce A et al. (Eds). Endotext. South Dartmouth (MA): MDText.com, Inc.; 2000; 2000. https://www.ncbi. nlm.nih.gov/books/NBK279167/

[2] Rubino F, Puhl RM, Cummings DE et al. Joint international consensus statement for ending stigma of obesity. Nat Med 2020; 26: 485-497

[3] Huq S, Todkar S, Lahiri SW. Patient perspectives on obesity management: Need for greater discussion of BMI and weight-loss options beyond diet and exercise, especially in patients with diabetes. Endocr Pract 2020; 26: 471-483

[4] Melcescu E, Griswold M, Xiang L et al. Prevalence and cardiometabolic associations of the glucocorticoid receptor gene polymorphisms $\mathrm{N} 363 \mathrm{~S}$ and Bcll in obese and non-obese black and white Mississippians. Hormones (Athens) 2012; 11: 166-177

[5] Centers for Disease Control and Prevention. National diabetes statistics report 2020. In: Centers for disease control and prevention, U.S. dept of health and human services. Atlanta, GA: 2020. https:// www.cdc.gov/diabetes/pdfs/data/statistics/national-diabetes-statistics-report.pdf

[6] Koch CA, Bartel M], Weinberg DS. Possible mechanisms: hyperinsulinemia and endocrine disrupting chemicals. Dtsch Arztebl International 2021; 118: 271

[7] Argyrakopoulou G, Dalamaga M, Spyrou N et al. Gender differences in obesity-related cancers. Curr Obes Rep 2021; 10: 100-115

[8] Centers for Disease Control and Prevention. Prevalence of overweight, obesity, and severe obesity among adults age 20 and Over: United States, 1960-1962 through 2015-2016; 2018. https://www. cdc.gov/nchs/data/hestat/obesity-adult-17-18/overweight-obesity-adults-H.pdf

[9] Wikipedia contributors. Eunice Newton foote. Wikipedia, The Free Encyclopedia. https://en.wikipedia.org/w/index. php?title = Eunice_ Newton_Foote\&oldid = 1019766611; 10 June 2021

[10] United States Environmental Protection Agency. Global greenhouse gas emissions data. https://www.epa.gov/ghgemissions/global-greenhouse-gas-emissions-data; June 11, 2021

[11] Wikipedia contributors. Greenhouse gas emissions. Wikipedia, The Free Encyclopedia. https://en.wikipedia.org/w/index.php?title $=$ Greenhouse_gas_emissions\&oldid = 1026926698; 11 June 2021

[12] Ritchie $\mathrm{H}$, Roser $\mathrm{M} . \mathrm{CO}_{2}$ and greenhouse gas emissions. Our world in data.org. 2020

[13] Willett W, Rockström J, Loken B et al. Food in the Anthropocene: the EAT-Lancet commission on healthy diets from sustainable food systems. Lancet 2019; 393: 447-492

[14] Wikipedia contributors. Population growth. Wikipedia, The Free Encyclopedia; 2021; https://en.wikipedia.org/w/index.php?title $=$ Population_growth\&oldid $=1019039554$
[15] Shiels MS, Almeida JS, García-Closas M et al. Impact of population growth and aging on estimates of excess U.S. deaths during the COVID-19 pandemic, March to August 2020. Ann Intern Med 2021; 174: $437-443$

[16] Cefalu WT, Rodgers GP. COVID-19 and metabolic diseases: a heightened awareness of health inequities and a renewed focus for research priorities. Cell Metab 2021; 33: 473-478

[17] Shi Z, Yan A, Zimmet P et al. COVID-19, diabetes, and associated health outcomes in China: results from a nationwide survey of 10545 adults. Horm Metab Res 2021; 53: 301-310

[18] Vo DH, Ho CM. Foreign investment, economic growth, and environmental degradation since the 1986 "Economic Renovation" in Vietnam. Environ Sci Pollut Res Int 2021; 1-11

[19] Aslan A, Destek MA, Okumus I. Bootstrap rolling window estimation approach to analysis of the environment Kuznets curve hypothesis: evidence from the USA. Environ Sci Pollut Res Int 2018; 25: 2402-2408

[20] An R, Ji M, Zhang S. Global warming and obesity: a systematic review. Obes Rev 2018; 19: 150-163

[21] Kanazawa S. Does global warming contribute to the obesity epidemic? Environ Res 2020; 182: 108962

[22] Turner JB, Kumar A, Koch CA. The effects of indoor and outdoor temperature on metabolic rate and adipose tissue - the Mississippi perspective on the obesity epidemic. Rev Endocr Metab Disord 2016; 17: $61-71$

[23] Krotkiewski M, Björntorp P, Sjöström L et al. Impact of obesity on metabolism in men and women. Importance of regional adipose tissue distribution. J Clin Invest 1983; 72: 1150-1162

[24] Johnson R], Lanaspa MA, Fox JW. Upper paleolithic figurines showing women with obesity may represent survival symbols of climatic change. Obesity (Silver Spring) 2021; 29: 11-15

[25] Magkos F, Tetens I, Bügel SG et al. The environmental foodprint of obesity. Obesity (Silver Spring) 2020; 28: 73-79

[26] Stone T, DiPietro L, Stachenfeld NS. Exercise treatment of obesity. In: Feingold KR, Anawalt B, Boyce A et al. eds. Endotext.South Dartmouth (MA): MDText.com, Inc.; Copyright @ 2000-2021, MDText.com, Inc. 2000

[27] Qiu S, Cai X, Sun Z et al. Chronic exercise training and circulating irisin in adults: A meta-analysis. Sports Med 2015; 45: 1577-1588

[28] Rodríguez A, Becerril S, Ezquerro $S$ et al. Crosstalk between adipokines and myokines in fat browning. Acta Physiol (Oxf) 2017; 219: 362-381

[29] Tsuchiya Y, Ando D, Takamatsu K et al. Resistance exercise induces a greater irisin response than endurance exercise. Metabolism 2015; 64: $1042-1050$

[30] Oliveira FR, Mamede M, Bizzi MF et al. Effects of short term metformin treatment on brown adipose tissue activity and plasma irisin levels in women with polycystic ovary syndrome: A randomized controlled trial. Horm Metab Res 2020; 52: 718-723

[31] Kurylowicz A, Jonas M, Lisik W et al. Obesity is associated with a decrease in expression but not with the hypermethylation of thermogenesis-related genes in adipose tissues. J Transl Med 2015; 13: 31

[32] da Silva MM, Gonçalves CFL, Miranda-Alves L et al. Inhibition of type 1 iodothyronine deiodinase by bisphenol A. Horm Metab Res 2019; 51: 671-677

[33] Celi FS, Le TN, Ni B. Physiology and relevance of human adaptive thermogenesis response. Trends Endocrinol Metab 2015; 26 : 238-247

[34] Bakker LE, Boon MR, van der Linden RA et al. Brown adipose tissue volume in healthy lean south Asian adults compared with white Caucasians: a prospective, case-controlled observational study. Lancet Diabetes Endocrinol 2014; 2: 210-217 
[35] Johnson F, Mavrogianni A, Ucci M et al. Could increased time spent in a thermal comfort zone contribute to population increases in obesity? Obes Rev 2011; 12: 543-551

[36] Mavrogianni A, Johnson F, Ucci M et al. Historic variations in winter indoor domestic temperatures and potential implications for body Wwight gain. Indoor Built Environ 2013; 22: 360-375

[37] Hamann A, Münzberg H, Tafel J et al. Some may feel hot: significance of thermogenesis for energy metabolism and the treatment of obesity. Dtsch Med Wochenschr 2001; 126: 241-246

[38] Pontzer H, Durazo-Arvizu R, Dugas LR et al. Constrained total energy expenditure and metabolic adaptation to physical activity in adult humans. Curr Biol 2016; 26: 410-417

[39] Maushart Cl, Loeliger R, Gashi G et al. Resolution of hypothyroidism restores cold-induced thermogenesis in humans. Thyroid 2019; 29: 493-501

[40] De Munck TJI, Xu P, Vanderfeesten BL] et al. The role of brown adipose tissue in the development and treatment of nonalcoholic steatohepatitis: an exploratory gene expression study in mice. Horm Metab Res 2020; 52: 869-876

[41] Meade RD, Akerman AP, Notley SR et al. Physiological factors characterizing heat-vulnerable older adults: A narrative review. Environ Int 2020; 144: 105909

[42] Vandentorren S, Bretin P, Zeghnoun A et al. August 2003 heat wave in France: risk factors for death of elderly people living at home. Eur J Public Health 2006; 16: 583-591

[43] Speakman JR. Obesity and thermoregulation. Handb Clin Neurol 2018; 156: 431-443

[44] Henschel A. Obesity as an occupational hazard. Can J Public Health 1967; 58: 491-493

[45] An R, Zhang S, ji M et al. Impact of ambient air pollution on physical activity among adults: a systematic review and meta-analysis. Perspect Public Health 2018; 138: 111-121

[46] United Nations Climate Change. The Paris agreement. 2016. https:// unfccc.int/process-and-meetings/the-paris-agreement/the-paris-agreement; June 11, 2021

[47] Sachsen.de. Trockenheit 2018 - Ist das die Zukunft? 2018. https:// www.klima.sachsen.de/trockenheit-2018-ist-das-die-zukunft-13084. html; June 11, 2021

[48] Wikipedia contributors. Iceberg A-68. Wikipedia, The Free Encyclopedia. https://en.wikipedia.org/w/index. php?title = Iceberg_A-68\&oldid = 1024943736; 11 June 2021

[49] Asbjørnsen H, Årthun M, Skagseth Ø et al. Mechanisms underlying recent arctic atlantification. Geophys Res Lett 2020; 47: e2020GL088036

[50] Martens ], Wild B, Muschitiello F et al. Remobilization of dormant carbon from Siberian-Arctic permafrost during three past warming events. Sci Adv 2020; 6

[51] IPCC 2014. Climate Change 2014: Synthesis Report. Contribution of working groups I, II and III to the fifth assessment report of the intergovernmental panel on climate change [Core Writing Team, R.K. Pachauri and L.A. Meyer, (Eds.)]. IPCC; Geneva, Switzerland: 151. pp

[52] Pojani D, Stead D. Sustainable urban transport in the developing world: beyond megacities. Sustainability 2015; 7: 7784-7805

[53] Exklusiv-Muenchen.de. Elektroauto ja oder nein? Digitaler E-AutoRechner mit Benziner-Vergleich. 2021. https://www.exklusiv-muenchen.de/exklusive-autos/elektroauto-ja-oder-nein-digitaler-e-auto-rechner-mit-benziner-vergleich-55738

[54] Wietschel M, Kühnbach M, Rüdiger D. Die aktuelle Treibhausgasemissionsbilanz von Elektrofahrzeugen in Deutschland. https://www.isi. fraunhofer.de/content/dam/isi/dokumente/sustainability-innovation/2019/WP02-2019_Treibhausgasemissionsbilanz_von_Fahrzeugen.pdf
[55] Schneyder E. The new green heart of Düsseldorf. https://www. ubm-development.com/magazin/en/the-new-green-heart-of-dusseldorf/

[56] Wikipedia contributors. Sponge city. Wikipedia, The Free Encyclopedia. https://en.wikipedia.org/w/index.php?title=Sponge_city\&ol$\operatorname{did}=1022895860 ; 11$ June 2021

[57] Le Quéré C, Jackson RB, Jones MW et al. Temporary reduction in daily global $\mathrm{CO}_{2}$ emissions during the COVID-19 forced confinement. Nat Climate Change 2020; 10: 647-653

[58] Wikipedia contributors. Desertification. Wikipedia, The Free Encyclopedia. https://en. wikipedia.org/w/index.php?title = Desertification\&oldid = 1025651755; 11 June 2021

[59] Wikipedia contributors. Moorland. Wikipedia, The Free Encyclopedia. https://en.wikipedia.org/w/index.php?title = Moorland\&ol$\operatorname{did}=1025370663 ; 11$ June 2021

[60] U.S. Department of Agriculture. Agroforestry; https://www.usda.gov/ topics/forestry/agroforestry

[61] Goverment of Canada. Indicator: Forest carbon emissions and removals. 2020. https://www.nrcan.gc.ca/our-natural-resources/ forests-forestry/state-canadas-forests-report/how-does-disturbanceshape-canad/indicator-carbon-emissions-removals/16552

[62] Wikipedia contributors. Carbon capture and storage. Wikipedia, The Free Encyclopedia. https://en.wikipedia.org/w/index. php?title = Carbon_capture_and_storage\&oldid = 1026667695; 11 June 2021

[63] Global CCS Institute. Norway's flagship CCS project northern lights receives green light by project partners. 2020. https://www. globalccsinstitute.com/news-media/press-room/media-releases/ norways-flagship-ccs-project-northern-lights-receives-green-lightby-project-partners/

[64] Ministry of Economy Trade and Industry. Report on large-scale CCS demonstration project compiled. 2020. https://www.meti.go.jp/ english/press/2020/0515_004.html

[65] Wikipedia contributors. CarbFix. Wikipedia, The Free Encyclopedia. https://en.wikipedia.org/w/index.php?title $=$ CarbFix\&ol$\operatorname{did}=1024750720 ; 11$ June 2021

[66] Yacine Y, Allhoff KT, Weinbach A et al. Collapse and rescue of evolutionary food webs under global warming. J Anim Ecol 2021; 90: 710-722

[67] Gubbi SWR, Hannah-Shmouni F, Koch CA. Basic concepts in environmental endocrinology. In: Pivonello R, Diamanti-Kandarakis E, (Eds.) Environmental endocrinology and endocrine disruptors endocrine and endocrine-targeted actions and related human diseases. New York, Heidelberg: Springer; 2021

[68] Kassotis CD, Nagel SC, Stapleton HM. Unconventional oil and gas chemicals and wastewater-impacted water samples promote adipogenesis via PPARy-dependent and independent mechanisms in 3T3-L1 cells. Sci Total Environ 2018; 640-641: 1601-1610

[69] Demeneix BA. How fossil fuel-derived pesticides and plastics harm health, biodiversity, and the climate. Lancet Diabetes Endocrinol 2020; 8: 462-464

[70] Wagner DL. Insect declines in the Anthropocene. Ann Rev Entomol 2020; 65: 457-480

[71] Darbre PD. Endocrine disruptors and obesity. Curr Obes Rep 2017; 6: $18-27$

[72] Morley NJ, Lewis JW. Temperature stress and parasitism of endothermic hosts under climate change. Trends Parasitol 2014; 30: 221-227

[73] Boyles JG, Seebacher F, Smit B et al. Adaptive thermoregulation in endotherms may alter responses to climate change. Integr Comp Biol 2011; 51: 676-690

[74] Jenssen BM. Endocrine-disrupting chemicals and climate change: A worst-case combination for arctic marine mammals and seabirds? Environ Health Perspect 2006; 114: 76-80 
[75] Swinburn BA, Kraak VI, Allender S et al. The global syndemic of obesity, undernutrition, and climate change: The Lancet commission report. Lancet 2019; 393: 791-846

[76] Trasande L, Zoeller RT, Hass U et al. Estimating burden and disease costs of exposure to endocrine-disrupting chemicals in the European union. J Clin Endocrinol Metab 2015; 100: 1245-1255

[77] Nikinmaa M. Climate change and ocean acidification-interactions with aquatic toxicology. Aquat Toxicol 2013; 126: 365-372

[78] Dworjanyn SA, Byrne M. Impacts of ocean acidification on sea urchin growth across the juvenile to mature adult life-stage transition is mitigated by warming. Proc Biol Sci 2018; 285: DOI: 10.1098/ rspb.2017.2684

[79] Henehan M], Ridgwell A, Thomas E et al. Rapid ocean acidification and protracted earth system recovery followed the end-Cretaceous Chicxulub impact. Proc Natl Acad Sci U S A 2019; 116: 22500-22504

[80] Parker LM, Ross PM, O'Connor WA. Comparing the effect of elevated $\mathrm{pCO}_{2}$ and temperature on the fertilization and early development of two species of oysters. Marine Biol 2010; 157: 2435-2452

[81] Singh A, Agrawal M. Acid rain and its ecological consequences. ] Environ Biol 2008; 29: 15-24

[82] Barouki R, Kogevinas M, Audouze K et al. The COVID-19 pandemic and global environmental change: Emerging research needs. Environ Int 2021; 146: 106272. doi:10.1016/j.envint.2020.106272

[83] Liu Z, Ciais P, Deng Z et al. Near-real-time monitoring of global $\mathrm{CO}_{2}$ emissions reveals the effects of the COVID-19 pandemic. Nat Commun 2020; 11: 5172

[84] Tollefson J. COVID curbed carbon emissions in 2020 - but not by much. Nature 2021; 589: 343

[85] NCSL. Public education's response to the coronavirus (COVID-19) pandemic. 2021. https://www.ncsl.org/research/education/ public-education-response-to-coronavirus-covid-19.aspx

[86] Pietrobelli A, Pecoraro L, Ferruzzi A et al. Effects of COVID-19 lockdown on lifestyle behaviors in children with obesity living in Verona, Italy: a longitudinal study. Obesity (Silver Spring) 2020; 28: 1382-1385

[87] Kumar S, Kelly AS. Review of childhood obesity: from epidemiology, etiology, and comorbidities to clinical assessment and treatment. Mayo Clin Proc 2017; 92: 251-265

[88] Shekhar S, Wurth R, Kamilaris CDC et al. Endocrine conditions and COVID-19. Horm Metab Res 2020; 52: 471-484

[89] Bornstein SR, Voit-Bak K, Schmidt D et al. Is there a role for environmental and metabolic factors predisposing to severe COVID-19? Horm Metab Res 2020; 52: 540-546

[90] Hoong CWS, Hussain I, Aravamudan VM et al. Obesity is associated with poor Covid-19 outcomes: A systematic review and meta-analysis. Horm Metab Res 2021; 53: 85-93

[91] Zachary Z, Brianna F, Brianna L et al. Self-quarantine and weight gain related risk factors during the COVID-19 pandemic. Obes Res Clin Pract 2020; 14: 210-216

[92] Bornstein S, Guan K, Brunßen C et al. The transcampus metabolic training programme explores the link of SARS-CoV-2 virus to metabolic disease. Horm Metab Res 2021; 53: 204-206

[93] Piercy KL, Troiano RP. Physical Activity Guidelines for Americans From the US Department of Health and Human Services. Circ Cardiovasc Qual Outcomes 2018; 11: e005263

[94] Pinto AJ, Dunstan DW, Owen N et al. Combating physical inactivity during the COVID-19 pandemic. Nat Rev Rheumatol 2020; 16: 347-348

[95] American Psychological Association. How and why to get children moving now. 2020. https://www.apa.org/topics/covid-19/ children-exercise-strategies

[96] An R. Projecting the impact of the coronavirus disease-2019 pandemic on childhood obesity in the United States: A microsimulation model. J Sport Health Sci 2020; 9: 302-312
[97] Naik Y, Allen DB, Eickhoff J et al. Stabilization of BMlz score is associated with a decrease in visceral fat in children with obesity. Horm Metab Res 2020; 52: 527-531

[98] Scholl J. Ernährung und Klima: Fleischfrei gesund und klimafreundlich essen - die Evidenz fehlt. Deutsch Ärztebl 2020; 117: A 1384-A 1388

[99] Frank M, Darren H.No. Four pounds of beef doesn't equal the emissions of a transatlantic flight. 2019. https://ghgguru.faculty. ucdavis.edu/2019/09/26/no-four-pounds-of-beef-doesnt-equal-theemissions-of-a-transatlantic-flight/

[100] Friend T. Can a burger help solve climate change? 2019. https:// www.newyorker.com/magazine/2019/09/30/can-a-burger-helpsolve-climate-change

[101] Han MA, Zeraatkar D, Guyatt GH et al. Reduction of red and processed meat intake and cancer mortality and incidence: a systematic review and meta-analysis of cohort studies. Ann Intern Med 2019; 171: 711-720

[102] Zeraatkar D, Han MA, Guyatt GH et al. Red and processed meat consumption and risk for all-cause mortality and cardiometabolic outcomes: a systematic review and meta-analysis of cohort studies. Ann Intern Med 2019; 171: 703-710

[103] Zeraatkar D, Johnston BC, Bartoszko ] et al. Effect of lower versus higher red meat intake on cardiometabolic and cancer o0utcomes: a systematic review of randomized trials. Ann Intern Med 2019; 171: 721-731

[104] Johnston BC, Zeraatkar D, Han MA et al. Unprocessed Red Meat and Processed Meat Consumption: Dietary Guideline Recommendations From the Nutritional Recommendations (NutriRECS) Consortium. Ann Intern Med 2019; 171: 756-764

[105] United States Environmental Protection Agency. Inventory of U.S Greenhouse gas emissions and sinks: 1990-2018. 2020. https:// www.epa.gov/ghgemissions/inventory-us-greenhouse-gas-emissions-and-sinks-1990-2018

[106] Brown ME, Antle JM, Backlund P et al. Climate change, global food security, and the U.S. food system. 2015. https://www.usda.gov/ sites/default/files/documents/FullAssessment.pdf

[107] Food and Agriculture Organization of the United States. Food wastage footprint \& climate change. 2015; http://www.fao.org/3/ bb144e/bb144e.pdf

[108] Dietz WH. Climate change and malnutrition: we need to act now. J Clin Invest 2020; 130: 556-558

[109] Aleksandrowicz L, Green R, Joy E] et al. The impacts of dietary change on greenhouse gas emissions, land use, water use, and health: a systematic review. PLoS One 2016; 11: e0165797

[110] Sáez-Almendros S, Obrador B, Bach-Faig A et al. Environmental footprints of Mediterranean versus Western dietary patterns: beyond the health benefits of the Mediterranean diet. Environ Health 2013; 12: 118

[111] Seid H, Rosenbaum M. Low carbohydrate and low-fat diets: what we don't know and why we should know it. Nutrients 2019; 11

[112] Aronne LJ, Hall KD, MJ J et al. Describing the weight-reduced state: physiology, behavior, and interventions. Obesity (Silver Spring) 2021; 29: S9-S24

[113] Rosenbaum M, Agurs-Collins T, Bray MS et al. Accumulating data to optimally predict obesity treatment (ADOPT): recommendations from the biological domain. Obesity (Silver Spring) 2018; 26: S25-S34

[114] Tak Y], Lee SY. Long-term efficacy and safety of anti-obesity treatment: where do we stand? Curr Obes Rep 2021; 10: 14-30

[115] Verhaegen AA, Van Gaal LF. Drugs affecting body weight, body fat distribution, and metabolic function-mechanisms and possible therapeutic or preventive measures: an update. Curr Obes Rep 2021; 10: $1-13$ 